\title{
КОНЫЮГАТЫ СЕСКВИТЕРПЕНОВЫХ ЛАКТОНОВ И АНТРАЦИКЛИНОВЫХ АНТИБИОТИКОВ КАК ЦИТОТОКСИЧЕСКИЕ АГЕНТЫ
}

\author{
Е.Ю. Яндулова, М.Е. Неганова, А.В. Семаков, Ю.Р. Александрова, \\ С.А. Пухов, Л.В. Аникина, С.Г. Клочков \\ Институт физиологически активных веществ Российской академии наук, \\ 142432, Россия, г. Черноголовка, Северный проезд, д. 1.
}

DOI: 10.19163/MedChemRussia2021-2021-369

E-mail:yandulova @ipac.ac.ru

Одним из перспективных классов химиотерапевтических средств являются антрациклиновые антибиотики, однако низкая селективность и высокая токсичность по отношению к здоровым тканям ограничивают их применение. Как известно, антрациклины обладают кумулятивной кардиотоксичностью, обусловленной в том числе высоким прооксидантным эффектом и провоцированием дисфункции митохондрий.

Для преодоления вышеизложенных ограничений были получены бифармакофорные молекулы, содержащие в своей структуре фрагмент известных антрациклиновых антибиотиков даунорубицина и доксорубицина, а также природные сесквитерпеновые лактоны.

Синтезированные конъюгаты проявили выраженные цитотоксические свойства по отношению ко всем использованным линиям опухолевых клеток, сопоставимые с действием доксо- и даунорубицина, без усиления токсического действия на нормальные клетки для большинства конъюгатов. Исследуемые конъюгаты показывали снижение повреждающего действия на функционирование митохондрий сердца крыс, значительное снижение окислительного стресса. Кроме того, они ингибировали анаэробный гликолиз, являющийся основным метаболическим путем получения энергии неопластическими клетками.

Полученные результаты позволяют подтвердить предположение о том, что химическая модификация молекул антрациклиновых антибиотиков доксо- и даунорубицина сесквитерпеновыми лактонами может быть перспективной стратегией создания потенциальных противоопухолевых химиотерапевтических препаратов с выраженным цитотоксическим действием на опухолевые клетки и сниженным повреждающим действием на здоровые клетки организма человека. 